P-ISSN: 2615-1723

E-ISSN: 2615-1766

Oktober 2019
Jurnal Riset Pendidikan Dasar

02 (2), (2019) 130-135

Submitted: Juli, Accepted Agustus, Published: Oktober

\title{
Pengaruh Pendekatan Saintifik Terhadap Hasil Belajar dalam Pembelajaran IPA di Sekolah Dasar
}

\author{
Dina Dahliana, Nike Sri Setiawati, \& Taufina \\ Prodi Pendidikan Dasar, FIP Universitas Negeri Padang, Indonesia \\ Korespondensi. E-mail: dinadahliana23unp@gmail.com
}

\begin{abstract}
Abstrak
Tujuan dari penelitian ini yaitu untuk pengaruh penggunaan pendekatan saintifik terhadap hasil belajar siswa dalam pembelajaran IPA di SD Negeri 10 Lambung Bukit Kecamatan Pauh, Padang. Penelitian ini merupakan penelitian eksperimen jenis Quasi Eksperimental Design dengan rancangan The Static Comparison: Randomized Control Group Only Design. Populasi dalam penelitian ini adalah seluruh siswa kelas IV semester II SD Negeri 10 Lambung Bukit Kecamatan Pauh yang terdiri dari 2 kelas berjumlah 47 orang. Berdasarkan analisis data diperoleh hasil pengujian terhadap data dari kelas sampel yaitu berdistribusi normal dan homogen. Selanjutnya dilakukan uji hipotesis dengan uji-t menunjukkan $t_{\text {hitung }}=2,464$ dan $\mathrm{t}_{\text {tabel }}=1,677$ dengan $\mathrm{db}=47(\mathrm{n} 1+\mathrm{n} 2-2=24+25-2=47)$ dan taraf signifikan $5 \%$. Berdasarkan pengujian $t_{\text {hitung }} \mathrm{t}_{\text {tabel }}(2,464>1,677)$ maka $\mathrm{H}_{0}$ ditolak dan $\mathrm{H}_{1}$ diterima, dengan kesimpulan bahwa "hasil belajar siswa yang menggunakan pendekatan saintifik lebih baik daripada hasil belajar siswa yang tanpa menggunakan pendekatan saintifik terhadap hasil belajar siswa dalam pembelajaran IPA di kelas IV SD Negeri 10 Lambung Bukit Kecamatan Pauh"
\end{abstract}

Kata Kunci: Pendekatan Saintifik; Hasil Belajar IPA

\section{The Effect of Scientific Approaches Against Learning Outcomes in Science Learning in Elementary School}

\begin{abstract}
The purpose of this study is to influence the use of a scientific approach to student learning outcomes in science learning in SD Negeri 10 Lambung Bukit, Pauh District, Padang. This research is an experimental research type Quasi Experimental Design with the design of The Static Comparison: Randomized Control Group Only Design. The population in this study were all students in grade IV semester II SD Negeri 10 Lambung Bukit District Pauh which consisted of 2 classes totaling 47 people. Based on the data analysis, the results of testing of the data from the sample class are normally distributed and homogeneous. Furthermore, hypothesis testing was done by t-test showing tcount $=2.464$ and ttable $=1.677$ with $\mathrm{db}=47$ $(\mathrm{n} 1+\mathrm{n} 2-2=24+25-2=47)$ and a significant level of $5 \%$. Based on the $\mathrm{t}$-test $>\mathrm{t}$ table $(2,464>1,677)$ then $\mathrm{H} 0$ is rejected and $\mathrm{H} 1$ is accepted, with the conclusion that "student learning outcomes that use a scientific approach are better than student learning outcomes without using a scientific approach to student learning outcomes in science learning in grade IV elementary school Negeri 10 Lambung Bukit District Pauh ".
\end{abstract}

Keywords: Scientific Approach; Science Learning Outcomes

Copyright $@ 2019$, JRPD, ISSN 2615 - 1723 (Print), ISSN 2615 - 1766 (Online) 


\section{Jurnal Riset Pendidikan Dasar, 02 (2), Oktober 2019 (130-135)}

Dina Dahliana, Nike Sri Setiawati, \& Taufina

\section{PENDAHULUAN}

Keberhasilan suatu pendidikan di sekolah salah satu kuncinya adalah keberhasilan guru dalam menyajikan materi pelajaran yang dapat memfasilitasi siswanya untuk mencapai kompetensi yang diharapkan. Pada setiap kurikulum yang berlaku guru diharapkan mengembangkan pendekatan pembelajaran sesuai dengan kondisi lapangan seperti halnya dalam pembelajaran IPA.

IPA berhubungan dengan cara mencari tahu tentang alam secara sistematis sehingga IPA bukan hanya penguasaan kumpulan pengetahuan yang berupa faktafakta, konsep-konsep, atau prinsip-prinsip saja tetapi juga merupakan suatu pengetahuan proses penemuan. IPA merupakan bangun pengetahuan yang menggambarkan usaha, temuan, wawasan, dan kearifan yang bersifat kolektif dari umat manusia.

Ilmu Pengetahuan Alam Menurut Sukarno (dalam Wisudawati dan Sulistyowati, 2014:23), adalah ilmu yang mempelajari tentang sebab dan akibat kejadian-kejadian yang ada di alam ini. Kemudian menurut Wahyana, 1986 (dalam Trianto, 2014:136), IPA adalah suatu kumpulan pengetahuan tersusun secara sistematik, dan dalam penggunaannya secara umum terbatas pada gejala-gejala alam. Perkembangannya tidak hanya ditandai oleh adanya kumpulan fakta, tetapi oleh adanya metode ilmiah dan sikap ilmiah.

Berdasarkan definisi IPA di atas, dapat diambil kesimpulan bahwa IPA adalah suatu kumpulan teori yang sistematis, penerapannya secara umum terbatas pada gejala-gejala alam, lahir dan berkembang melalaui metode ilmiah seperti observasi dan eksperimen serta menuntut sikap ilmiah seperti rasa ingin tahu, terbuka, jujur, dan sebagainya. Dapat dipahami bahwa pembelajaran IPA merupakan pembelajaran berdasarkan pada prinsip-prinsip, proses yang mana dapat menumbuhkan sikap ilmiah siswa terhadap konsep-konsep pembelajaran IPA. Oleh karena itu pembelajaran IPA di sekolah dasar dilakukan dengan penyelidikan sederhana dan bukan hafalan kumpulan konsep IPA.

Dengan kegiatan-kegiatan tersebut pembelajaran IPA akan mendapat pembelajaran langsung melalui pengamatan, diskusi, dan penyelidikan sederhana sehingga dapat menumbuhkan sikap ilmiah siswa yang diindikasikan dengan merumuskan masalah, menarik kesimpulan sehingga mampu berfikir kritis melalui pembelajaran IPA. Pembelajaran IPA di SD pada umumnya masih berpusat pada guru atau masih menggunakan metode ceramah. Pembelajaran yang hanya mengandalkan ceramah dan hafalan cenderung kurang menarik dan membosankan bagi siswa. Dengan demikian tujuan pembelajaran itu sendiri akan sulit tercapai.

Permasalahan ini juga penulis temukan pada pembelajaran IPA di SD Negeri 10 Lambung Bukit Kecamatan Pauh yaitu pada tanggal 19 Januari 2017, 03 Februari 2017, dan pada tanggal 09 Februari 2017. Berdasarkan hasil observasi yang telah penulis lakukan dengan guru kelas IV pada semester I tahun ajaran 2016/2017, penulis menemukan masalah pada SD Negeri 10 Lambung Bukit Kecamatan Pauh kelas IV SD diantaranya; pada pembelajaran IPA, guru masih mengandalkan metode ceramah dan pembelajaran masih berpusat pada guru (Teacher Centered), siswa belum terbiasa untuk bertanya dalam proses pembelajaran, siswa belum dibiasakan berdiskusi dalam kelompok dan bekerjasama dengan siswa lain, siswa belum terbiasa mengeluarkan pendapat dalam pembelajaran serta hasil belajar siswa masih rendah.

Pembelajaran melalui pendekatan saintifik adalah proses pembelajaran yang dirancang sedemikian rupa agar peserta didik secara aktif mengonstruksi konsep, hukum atau prinsip melalui tahapan-tahapan 


\section{Jurnal Riset Pendidikan Dasar, 02 (2), Oktober 2019 (130-135)}

Dina Dahliana, Nike Sri Setiawati, \& Taufina

mengamati (untuk mengidentifikasi atau menemukan masalah), merumuskan masalah, mengajukan atau merumuskan hipotesis, mengumpulkan data dengan berbagai teknik, menganalisis data, menarik kesimpulan dan mengomunikasikan konsep, hukum atau prinsip yang ditemukan (Machin, A. 2014).

Nurul dalam Marjan, J., Arnyana, I. B. P., Si, M., Setiawan, I. G. A. N., \& Si, M. (2014), menyebutkan Pembelajaran berpendekatan saintifik merupakan pembelajaran yang menggunakan pendekatan ilmiah dan inkuiri, dimana siswa berperan secara langsung baik secara individu maupun kelompok untuk menggali konsep dan prinsip selama kegiatan pembelajaran, sedangkan tugas guru adalah mengarahkan proses belajar yang dilakukan siswa dan memberikan koreksi terhadap konsep dan prinsip yang didapatkan siswa

Pendekatan saintifik memiliki kelebihan pada penerapannya dalam proses pembelajaran, yaitu lebih menekankan pada keterampilan proses, seperti mengamati, mengklasifikasikan, mengukur, meramalkan, menjelaskan, dan meyimpulkan. (Hosnan (2014:34).

Kurangnya semangat siswa dalam pembelajaran IPA ini, menyebabkan rendahnya hasil belajar siswa. Salah satu upaya yang dapat dilakukan guru adalah dengan menggunakan pendekatan yang sesuai dan bervariasi dalam proses pembelajaran, sehingga siswa lebih aktif dan kreatif dalam pembelajaran, serta tujuan pembelajaran dapat tercapai. Oleh karena itu diperlukan pendekatan pembelajaran saintifik melibatkan siswa secara langsung dan pembelajaran yang berpusat pada siswa yaitu pada kegiatan mengamati, menanya, mencoba, menalar, dan mengkomunikasikan. Penggunaan pendekatan pembelajaran yang tepat akan membuat siswa lebih memahami materi pembelajaran dan akan meningkatkan hasil pembelajaran siswa.

Pendekatan yang dapat digunakan untuk memperbaiki hasil siswa dalam belajar terutama pada mata pelajaran IPA adalah pendekatan Saintifik. Dimana pembelajaran dengan pendekatan saintifik ini dirancang sedemikian rupa agar siswa secara aktif mengkonstruksi, konsep, hukum atau prinsip melalui tahapan-tahapan mengamati, merumuskan masalah, mengajukan atau merumuskan hipotesis, mengumpulkan data dengan berbagai teknik, menganalisis data, menarik kesimpulan dan mengomunikasikan konsep, hukum atau prinsip yang "ditemukan".

Pendekatan saintifik menurut Faisal (2014: 49), merupakan suatu pendekatan yang digunakan dalam pembelajaran dengan menitikberatkan pada penggunaan metode ilmiah dalam proses pembelajaran. Kemudian, menurut Daryanto (2014: 59), proses pembelajaran pada kurikulum 2013 untuk semua jenjang dilaksanakan dengan menggunakan pendekatan ilmiah (saintifik). Langkah-langkah pendekatan ilmiah (scientific appoach) dalam proses pembelajaran meliputi menggali informasi melalui pengamatan, bertanya, percobaan, kemudian mengolah data atau informasi, menyajikan data atau informasi, dilanjutkan dengan menganalisis, menalar, kemudian menyimpulkan, dan mencipta.

\section{METODE}

Penelitian ini dilakukan penelitian eksperimen yang merupakan penelitian yang dimaksud untuk mengetahui ada tidaknya akibat dari suatu yang dikenakan pada subjek selidik. Artinya, penelitian eksperimen mencoba meneliti ada tidaknya hubungan sebab akibat. Penelitian eksperimen yang akan digunakan adalah penelitian Quasi Experimental Design.

Rancangan penelitian yang digunakan adalah Randomized Control Group Only Design. Sampel dibagi menjadi dua kelompok, yaitu kelas eksperimen dan kelas kontrol. Perlakuan yang diberikan pada kelas eksperimen adalah menggunakan pendekatan pembelajaran Saintifik sedangkan pada kelas kontrol tidak 


\section{Jurnal Riset Pendidikan Dasar, 02 (2), Oktober 2019 (130-135)}

Dina Dahliana, Nike Sri Setiawati, \& Taufina

menggunakan pendekatan pembelajaran Saintifik.

Populasi dalam penelitian ini adalah seluruh siswa kelas IV SD Negeri 10 Lambung Bukit Kecamatan Pauh. Sampelnya adalah kelas IVA dan kelas IVB.

Dalam penelitian ini digunakan beberapa instrumen yang diperlukan, diantaranya yaitu Rencana Pelaksanaan Pembelajaran (RPP), kisi-kisi soal, soal tes, lembar jawab tes, dan kunci jawaban tes.

Teknik pengumpulan data yang digunakan dalam penelitian ini adalah tes. Teknik analisis data dilankukan dengan uji normalitas data digunakan untuk mengetahui data hasil penelitian berdistribusi normal atau tidak. Uji homogenitas tujuannya adalah untuk mengetahui apakah kelas sampel mempunyai variansi yang homogen atau tidak. Uji hipotesis bertujuan untuk melihat perbandingan apakah hasil belajar IPA siswa kelas IV berbeda secara signifikan, dengan hipotesis statistic.

\section{HASIL DAN PEMBAHASAN}

\section{Pelaksanaan Pembelajaran}

Kelas eksperimen diberi treatment
dengan pendekatan
pembelajaran saintifik, sedangkan pada kelas
control tidak diberikan treatment apapun artinya
tetap menggunakan pembelajaran yang biasa
digunakan oleh guru dalam mengajar yaitu
metode ceramah, tanya jawab dan evaluasi.
Treatment yang berbeda diantara kedua
kelompok tersebut dimaksudkan untuk
mengetahui pengaruh yang di timbulkan
terhadap hasil belajar siswa.

\section{Data tes hasil belajar}

Seletah dilakukan pembelajaran, diadakan tes akhir pada setiap kelas sampel. Diperoleh data nilai siswa kelas sampel sebagai berikut :
Tabel 1 Hasil Perhitungan Data Hasil Belajar

\begin{tabular}{cccccc}
\hline Kelas & $\overline{\mathbf{X}}$ & $\mathbf{N}$ & $\mathbf{S}$ & $\mathbf{X}_{\max }$ & $\mathbf{X}_{\min }$ \\
\hline Eksperimen & 82,3 & 24 & 14,72 & 100 & 50 \\
Kontrol & 73,2 & 25 & 12,02 & 90 & 45 \\
\hline
\end{tabular}

Berdasarkan Tabel 14 terlihat bahwa rata-rata hasil belajar IPA siswa kelas eksperimen $(\bar{x}=82,3)$ lebih tinggi dari rata-rata hasil belajar IPA siswa kelas kontrol $(\bar{x}=73,2)$. Simpangan baku kelas eksperimen $(S=14,72)$ lebih kecil dari simpangan baku kelas kontrol $(\mathrm{S}=12,02)$, hal ini menunjukkan bahwa pada kelas eksperimen memiliki keragaman yang kecil, sehingga menyebabkan nilai siswa tersebar tidak terlalu jauh dari nilai rata-rata kelas. Selanjutnya perolehan skor tertinggi dan terendah antara kelas eksperimen dan kelas kontrol memiliki skor yang berbeda, skor tertinggi siswa pada kelas eksperimen $\left(x_{\text {maks }}=100\right)$ lebih tinggi daripada kelas $\operatorname{kontrol}\left(x_{\text {maks }}=90\right)$, demikian pula jika dilihat dari skor terendah yang diperoleh siswa pada kelas eksperimen $\left(x_{\min }=50\right)$ lebih tinggi dibandingkan skor pada kelas kontrol $\left(x_{\min }=45\right)$.

Perbandingan rata-rata kelas eksperimen dan kelas control dapat dilihat pada Gambar 1 berikut:

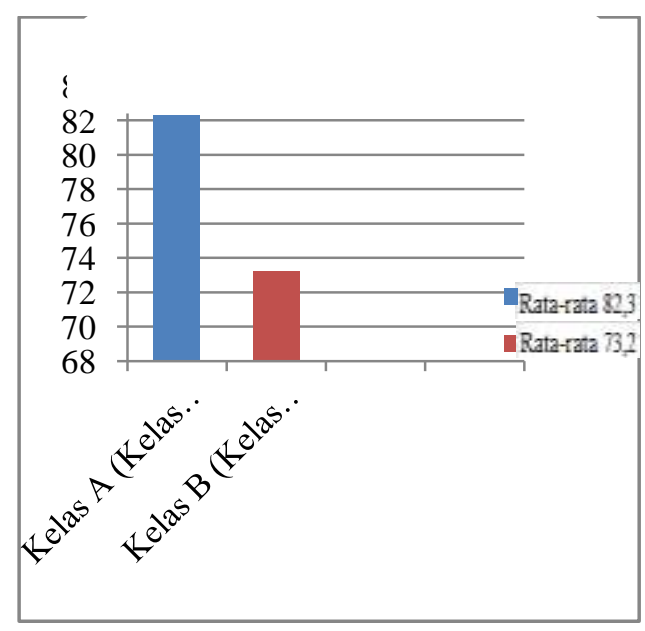

Gambar1. Diagram Rata-rata Kelas Eksperimen dan Kelas Kontrol 


\section{Jurnal Riset Pendidikan Dasar, 02 (2), Oktober 2019 (130-135)}

Dina Dahliana, Nike Sri Setiawati, \& Taufina

Disamping itu jumlah ketuntasan siswa di kelas eksperimen lebih banyak dari kelas kontrol. Hal ini dapat dilihat pada Tabel 14 berikut:

Tabel 2 Nilai Ketuntasan Siswa pada Kelaketrilospaimsiswdapadzeledas eksperimen lebih Kontrol

\begin{tabular}{|c|c|c|c|c|c|}
\hline \multirow{2}{*}{ Kelas } & Jumlah & \multicolumn{2}{|c|}{ Tuntas ( $\geq$} & \multicolumn{2}{c|}{ Tidaktuntas } \\
Siswa & \multicolumn{2}{|c|}{$\mathbf{7 5 )}$} & \\
\cline { 3 - 6 } & & Jumlah & \% & Jumlah & \% \\
\hline Ekperimen & 24 & 18 & 75 & 6 & 25 \\
\hline Kontrol & 25 & 15 & 60 & 10 & 40 \\
\hline
\end{tabular}

Berdasarkan Tabel 2 di atas, terlihat bahwa persentase ketuntasan siswa kelas eksperimen lebih tinggi dari persentase ketuntasan siswa kelas kontrol. Pada kelas eksperimen, jumlah siswa yang tuntas ada 18 siswa atau $75 \%$ dan yang tidak tuntas ada 6 siswa atau $25 \%$ dari jumlah keseluruhan siswa kelas eksperimen yaitu 24 siswa. Sedangkan pada kelas control 15 siswa atau $60 \%$ yang tuntas dan 10 siswa atau $40 \%$ tidak tuntas dari 25 siswa. Persentase ketuntasan kelas sampel dapat disajikan dalam bentuk diagram berikut:

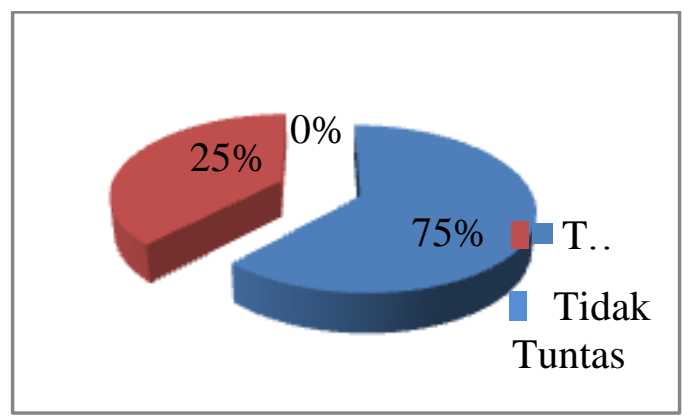

Gambar 2. Diagram Persentase Ketuntasan Siswa Kelas Eksperimen

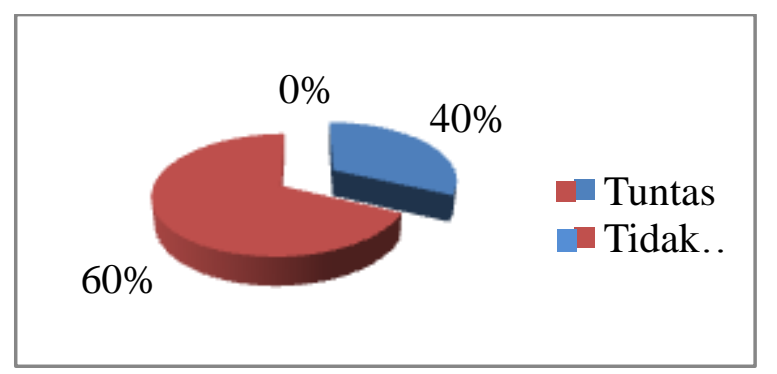

Gambar 3. Diagram Persentase Ketuntasan Siswa Kelas Kontrol

Berdasarkan Gambar 2 dan Gambar 3 di atas, terlihat bahwa perbandingan persentase tinggi dibandingkan persentase ketuntasan siswa pada kelas kontrol.

Berdasarkan pada analisis data yang telah didapatkan, maka terlihat bahwa terdapat pengaruh hasil belajar IPA siswa pada kelas eksperimen yang menggunakan pendekatan pembelajaran saintifik dengan kelas kontrol yang tanpa menggunakan pendekatan pembelajaran saintifik. Hal ini dapat dilihat dari nilai rata-rata siswa kelas eksperimen lebih tinggi dari nilai rata-rata siswa kelas kontrol. Nilai rata-rata siswa kelas eksperimen adalah 82,3 sedangkan nilai rata-rata siswa kelas control adalah 73,2.

Selanjutnya juga dapat dilihat dari hasil uji hipotesis dengan menggunakan uji-t. Dari hasil perhitungan diperoleh bahwa tolak $\mathrm{H}_{0}$ karena diperoleh $t_{\text {hitung }}=2,464$, lebih besar dari $t_{\text {tabel }}=1,677$. Sehingga dapat disimpulkan tolak $\mathrm{H}_{0}$, dengan kata lain "hasil belajar IPA siswa yang menggunakan pendekatan pembelajaran saintifik lebih baik daripada siswa yang tanpa menggunakan pendekatan pembelajaran saintifik di kelas IV SD Negeri 10 Lambung Bukit Kecamatan Pauh Tahun Ajaran 2017".

Berdasarkan hasil post-test, penggunaan pendekatan pembelajaran saintifik cocok diterapkan untuk menigkatkan hasil belajar siswa. Hal ini sesuai dengan teori DeVito (dalam Faisal, 2014:49), menjelaskan bahwa pendekatan saintifik adalah pendekatan pembelajaran yang memungkinkan terbudayakannya kecakapan berfikir ilmiah sekaligus terkembangkannya sense of inquiry dan kemampuan berfikir kreatif siswa. Melalui pendekatan saintifik memungkinkan siswa mengumpulkan data dengan objektif untuk memecahkan permasalahan. Oleh sebab itu pendekatan saintifik sering juga disebut sebagai pendekatan induktif. Hal ini disebabkan karena pendekatan saintifik dimulai dari hal-hal yang 


\section{Jurnal Riset Pendidikan Dasar, 02 (2), Oktober 2019 (130-135)}

Dina Dahliana, Nike Sri Setiawati, \& Taufina

bersifat spesifik ke simpulan yang bersifat general. Sehingga dapat meningkatkan hasil belajar siswa khususnya dalam pembelajaran IPA di SD.

Pembelajaran menggunakan pendekatan pembelajaran saintifik di kelompok eksperimen dikonsep dengan melibatkan siswa untuk melakukan pemecahan masalah dalam kelompok-kelompok, berpendapat dan menyajikan hasil diskusinya. Pembelajaran yang dimulai dari masalah yang dekat dengan kehidupan siswa dan dilakukan secara berkelompok akan membuat siswa menjadi lebih komunikatif. Siswa bekerja dalam kelompok, berinteraksi, saling mengajarkan dan melakukan presentasi. Dalam berkelompok siswa saling mencurahkan pendapatnya antar anggota kelompok, membuat karya untuk melaporkan hasil diskusi dan mempresentasikan hasil diskusi masalah di depan kelas.

Dari proses pembelajaran yang dilakukan menggunakan pendekatan pembelajaran saintifik di kelas eksperimen dan pembelajaran tanpa menggunakan pendekatan pembelajaran saintifik atau menggunakan metode ceramah di kelas kontrol, dapat dipahami bahwa kedua pendekatan tersebut memiliki pengaruh yang berbeda dalam meningkatkan kemampuan kognitif dan hasil belajar siswa. Pengaruh yang di timbulkan dari pendekatan pembelajaran saintifik lebih besar dibanding ceramah dan tanya jawab. Hal tersebut sesuai dengan pendapat yang menyatakan pendekatan saintifik memiliki kelebihan pada penerapannya dalam proses pembelajaran, yaitu lebih menekankan pada keterampilan proses, seperti mengamati, mengklasifikasikan, mengukur, meramalkan, menjelaskan, dan meyimpulkan. (Hosnan (2014:34).

\section{SIMPULAN}

Berdasarkan analisis data serta hasil penelitian dan pembahasan yang telah dikemukakan pada BAB sebelumnya terlihat dari nilai rata-rata yang diperoleh siswa di kelas eksperimen adalah 82,3 sedangkan kelas kontrol mempunyai rata-rata 73,2. Begitu juga dengan jumlah ketuntasan di kelas eksperimen lebih tinggi dibandingkan jumlah ketuntasan di kelas kontrol, yaitu 75\% pada kelas eksperimen dan $60 \%$ di kelas kotrol. Jadi, rata-rata dan jumlah ketuntasan pada kelas eksperimen lebih tinggi dibandingkan dari kelas kontrol.

Hasil perhitungan dengan Uji-t, yaitu diperoleh $t_{\text {hitung }}=2,464$ dan $t_{\text {tabel }}=1,677$ dengan $\mathrm{db}=47 \quad\left(\mathrm{n}_{1+} \mathrm{n}_{2}-2=24+25-2=47\right) \quad$ dimana $t_{\text {hitung }} t_{\text {tabel }} \quad(2,464>1,677)$ sehingga dapat ditarik kesimpulan bahwa "hasil belajar IPA siswa yang menggunakan pendekatan pembelajaran saintifik lebih baik dari pada hasil belajar IPA siswa yang tanpa menggunakan pendekatan pembelajaran saintifik) di kelas IV SD Negeri 10 Lambung Bukit Kecamatan Pauh".

\section{DAFTAR PUSTAKA}

Daryanto. (2014). Pendekatan Pembelajaran Saintifik Kurikulum 2013. Yogyakarta: Gava Media.

Faisal. 2014. Sukses Mengawal Kurikulum 2013 di SD (Teori dan Aplikasi). Yogyakarta: Diandra Creative.

Hosnan. 2014. Pendekatan Saintifik dan Konstektual dalam Pembelajaran Abad 21. Jakarta: Ghalia Indonesia.

Machin, A. (2014). Implementasi pendekatan saintifik, penanaman karakter dan konservasi pada pembelajaran materi pertumbuhan. Jurnal Pendidikan IPA Indonesia, 3(1).

Marjan, J., Arnyana, I. B. P., Si, M., Setiawan, I. G. A. N., \& Si, M. (2014). Pengaruh Pembelajaran Pendekatan Saintifik Terhadap Hasil Belajar Biologi Dan Keterampilan Proses Sains Siswa MA. Mu allimat NW Pancor Selong Kabupaten Lombok Timur Nusa Tenggara Barat. Jurnal Pendidikan dan Pembelajaran IPA Indonesia, 4(1).

Trianto. 2014. Model Pembelajaran Terpadu. Jakarta: PT Bumi Aksara.

Wisudawati \& Sulistyowati. (2014). Metodologi Pembelajaran IPA. Jakarta: Bumi Aksara.

Copyright C2019, JRPD, ISSN 2615 - 1723 (Print), ISSN 2615 - 1766 (Online) 